Article

\title{
First Isolation of Virulent Tenacibaculum maritimum Isolates from Diseased Orbicular Batfish (Platax orbicularis) Farmed in Tahiti Island
}

Pierre Lopez ${ }^{1, \dagger}$, Denis Saulnier ${ }^{1, *,+}$, Shital Swarup-Gaucher ${ }^{2}$, Rarahu David ${ }^{2}$, Christophe Lau ${ }^{2}$, Revahere Taputuarai ${ }^{2}{ }^{\oplus}$, Corinne Belliard ${ }^{1}$, Caline Basset ${ }^{1}\left(\mathbb{0}\right.$, Victor Labrune ${ }^{1}(0)$, Arnaud Marie ${ }^{3}$, Jean François Bernardet ${ }^{4}$ and Eric Duchaud ${ }^{4}(\mathbb{D}$

Citation: Lopez, P.; Saulnier, D.; Swarup-Gaucher, S.; David, R.; Lau,

C.; Taputuarai, R.; Belliard, C.; Basset,

C.; Labrune, V.; Marie, A.; et al. First Isolation of Virulent Tenacibaculum maritimum Isolates from Diseased Orbicular Batfish (Platax orbicularis) Farmed in Tahiti Island. Pathogens 2022, 11, 131. https://doi.org/ $10.3390 /$ pathogens 11020131

Academic Editor: Roberto Bermúdez Pose

Received: 13 December 2021

Accepted: 19 January 2022

Published: 21 January 2022

Publisher's Note: MDPI stays neutral with regard to jurisdictional claims in published maps and institutional affiliations.

Copyright: (C) 2022 by the authors. Licensee MDPI, Basel, Switzerland. This article is an open access article distributed under the terms and conditions of the Creative Commons Attribution (CC BY) license (https:/ / creativecommons.org/licenses/by/ $4.0 /)$.
1 Ifremer, IRD, Institut Louis-Malardé, Université Polynésie française, EIO, Labex Corail, F-98719 Taravao, French Polynesia; Pierre.Lopez2@ifremer.fr (P.L.); Corinne.Belliard@ifremer.fr (C.B.); Caline.Basset@ifremer.fr (C.B.); Victor.Labrune@ifremer.fr (V.L.)

2 DRM, Direction des Ressources Marines, Fare Ute Immeuble Le caill, F-98713 Papeete, French Polynesia; swarup_3@yahoo.com (S.S.-G.); Rarahu.David@partenaire-exterieur.ifremer.fr (R.D.); Christophe.Lau@ifremer.fr (C.L.); revaheretaputuarai04@gmail.com (R.T.)

3 Labofarm Finalab Veterinary Laboratory Group, 4 rue Théodore Botrel, 22600 Loudéac, France; a.marie@labofarm.com

4 Unité VIM, INRAE, Université Paris-Saclay, 78350 Jouy-en-Josas, France; jean-francois.bernardet@inrae.fr (J.F.B.); eric.duchaud@inrae.fr (E.D.)

* Correspondence: denis.saulnier@ifremer.fr

+ These authors contributed equally to this work.

\begin{abstract}
The orbicular batfish (Platax orbicularis), also called 'Paraha peue' in Tahitian, is the most important marine fish species reared in French Polynesia. Sudden and widespread outbreaks of severe 'white-patch disease' have occurred since 2011 in batfish farms one to three weeks after the transfer of juveniles from bio-secured hatcheries to lagoon cages. With cumulative mortality ranging from 20 to $90 \%$, the sustainability of aquaculture of this species is severely threatened. In this study, we report for the first time the isolation from diseased batfish of several isolates belonging to the species Tenacibaculum maritimum, a major pathogen of many marine fish species. Histopathological analysis, an experimental bath challenge and a field monitoring study showed that T. maritimum is associated with 'white-patch disease'. Moreover, molecular and serological analyses performed on representative isolates revealed some degree of genetic diversity among the isolates, a finding of primary importance for epidemiological studies and the development of management and control strategies such as vaccination.
\end{abstract}

Keywords: tenacibaculosis; Tenacibaculum maritimum; Platax orbicularis; aquaculture; serotyping; $16 \mathrm{~S}$ rRNA sequencing; multi-locus sequence analysis (MLSA); histology; qPCR diagnosis assay; experimental infection

\section{Introduction}

The orbicular batfish (Platax orbicularis, family Ephippidae) is a fish species inhabiting the top 30 metres depth over tropical reefs of the western Pacific [1]. It is widely distributed from the Indo-Pacific region to the Red Sea in East Africa, with a northern limit in south Japan and a southern limit in Australia and New Caledonia [2]. In French Polynesia, the batfish is highly appreciated as a food by the local population, but the wild stock is rapidly decreasing, probably as a result of high fishing pressure and climate change that severely disturb the coral communities [3]. In order to promote local, sustainable aquaculture, the governmental department of marine resources (DRM) decided to focus effort on captive breeding and rearing of orbicular batfish. Since 2011, the governmental hatchery VAIA (Vairao, Tahiti, French Polynesia) has produced eighty thousand fry annually, reared inland in bio-secure conditions (i.e., in filtered and UV treated seawater). Four production cycles 
are completed per year, allowing an annual production of 50-80 metric tons. One to two-month-old juvenile fish (mean weight, 1-10 g) are then transferred to different fish farms in lagoons. However, recurrent mortalities occur almost systematically during the first two months of growth in the lagoon cages, causing losses of 20-90\% of production and threatening the sustainability of aquaculture based on this species. One to three weeks following their transfer to net cages in the lagoons, the fish show symptoms of disease, with loss of appetite, frayed fins, whitish patches on the tegument, followed by ulcers, necrosis and death. Little was known about the status of pathogens and diseases associated with this tropical fish species under local farming conditions, and, consequently, this disease was simply named 'white-patch disease', based on the clinical symptoms. Light microscopy examination of fragments of skin lesions revealed abundant rod-shaped and gliding bacteria potentially belonging to the genus Tenacibaculum.

The genus Tenacibaculum (family Flavobacteriaceae, phylum Bacteroidetes) currently comprises 31 validly named species (http:/ / www.bacterio.net/tenacibaculum.html, accessed on 1 April 2021), all retrieved from marine environments [4]. Among these, T. dicentrarchi, T. discolor, T. finnmarkense, T. gallaicum, T. maritimum, T. piscium and T. soleae are responsible for ulcerative conditions that affect a large variety of cultured and wild marine fish species and are collectively known as tenacibaculosis [5]. Tenacibaculosis is generally associated with gross external lesions such as ulcerative and necrotic skin lesions, haemorrhagic mouth, frayed fins and tail rot [5]. The disease was originally described in 1977 in cultured red (Pagrus major) and black (Acanthopagrus schlegeli) seabream in Japan [6]. The causative agent was subsequently identified as Tenacibaculum maritimum (formerly Flexibacter maritimus) [7], a filamentous, Gram-negative, gliding bacterium. Since then, T. maritimum has been shown to be responsible for considerable losses in marine aquaculture worldwide, affecting a large variety of wild and cultured marine fish species. For example, T. maritimum was found to be associated with mortality events occurring in Atlantic salmon (Salmo salar) and rainbow trout (Oncorhynchus mykiss) in Australia [8], Chinook salmon (Oncorhynchus tshawytscha) in Canada [9], sole (Solea senegalensis) and turbot (Scophthalmus maximus) in Spain [10], sea bass (Dicentrarchus labrax) in Europe [11], Japanese flounder (Paralichthys olivaceus) in Japan [12], and black damselfish (Neoglyphieodon melas) and Picasso triggerfish (Rhinecanthus assasi) in Egypt [13]. Although other T. maritimum isolates have also been retrieved from outbreaks in other countries and host fish species, pathogenicity has not been confirmed using experimental challenges in any of these examples $[14,15]$.

In many cases, including some from the recent scientific literature [16], bacterial isolation and proper identification are usually not carried out, and tenacibaculosis diagnosis is often only based on clinical symptoms and microscopic observations. Indeed, the proper identification of the species involved in tenacibaculosis has long been hampered by a combination of factors, including the lack of selective culture medium to isolate Tenacibaculum strains responsible for outbreaks or to track/retrieve them from the different compartments of fish farms. Indeed, Tenacibaculum species are rather slow-growing and often only retrieved from external lesions (systemic infections seem rare). Consequently, bacterial cultures are almost systematically contaminated by fast-growing bacteria (e.g., Vibrio species), and obtaining pure cultures of Tenacibaculum is a challenge [17]. In addition, for over 3 decades (1977-2008), the only recognised pathogenic species in the genus was T. maritimum, and the recent discovery of an unforeseen diversity of pathogenic species in the genus was not followed by the development of the corresponding diagnostic tools [18].

The aims of the present study were to investigate the recurrent and acute outbreaks occurring in Platax orbicularis farms in French Polynesia, to characterise the causative agent using bacteriological, histological and molecular analyses, and then to conduct experimental challenges to confirm this causality, thus fulfilling Koch's postulates. 


\section{Results}

\subsection{Microscopic Examination and Isolation of Bacteria}

Two severe white-patch disease outbreaks, occurring within the first 2 months following transfer to net cages in a lagoon, were recorded in 2013 and 2016. These outbreaks occurred in two geographically distinct fish farming areas of Tahiti island (Tautira lagoon: $17^{\circ} 47^{\prime} 50^{\prime \prime} \mathrm{S}, 149^{\circ} 07^{\prime} 14^{\prime \prime} \mathrm{W}$, and Vairao lagoon: $17^{\circ} 48^{\prime} 22^{\prime \prime} \mathrm{S}, 149^{\circ} 17^{\prime} 36^{\prime \prime} \mathrm{W}$ ) with cumulative mortality reaching $80 \%$ and $62 \%$, respectively. The main clinical signs were loss of appetite, erratic swimming and ulcerative skin lesions (Figure 1A). Wet mount examination of the skin mucus of diseased batfish revealed a significant amount of long $(6.3 \pm 0.6 \mu \mathrm{m})$ and rod-shaped bacteria (Figure 1B). In contrast, no alterations or clinical signs were observed in the internal organs.

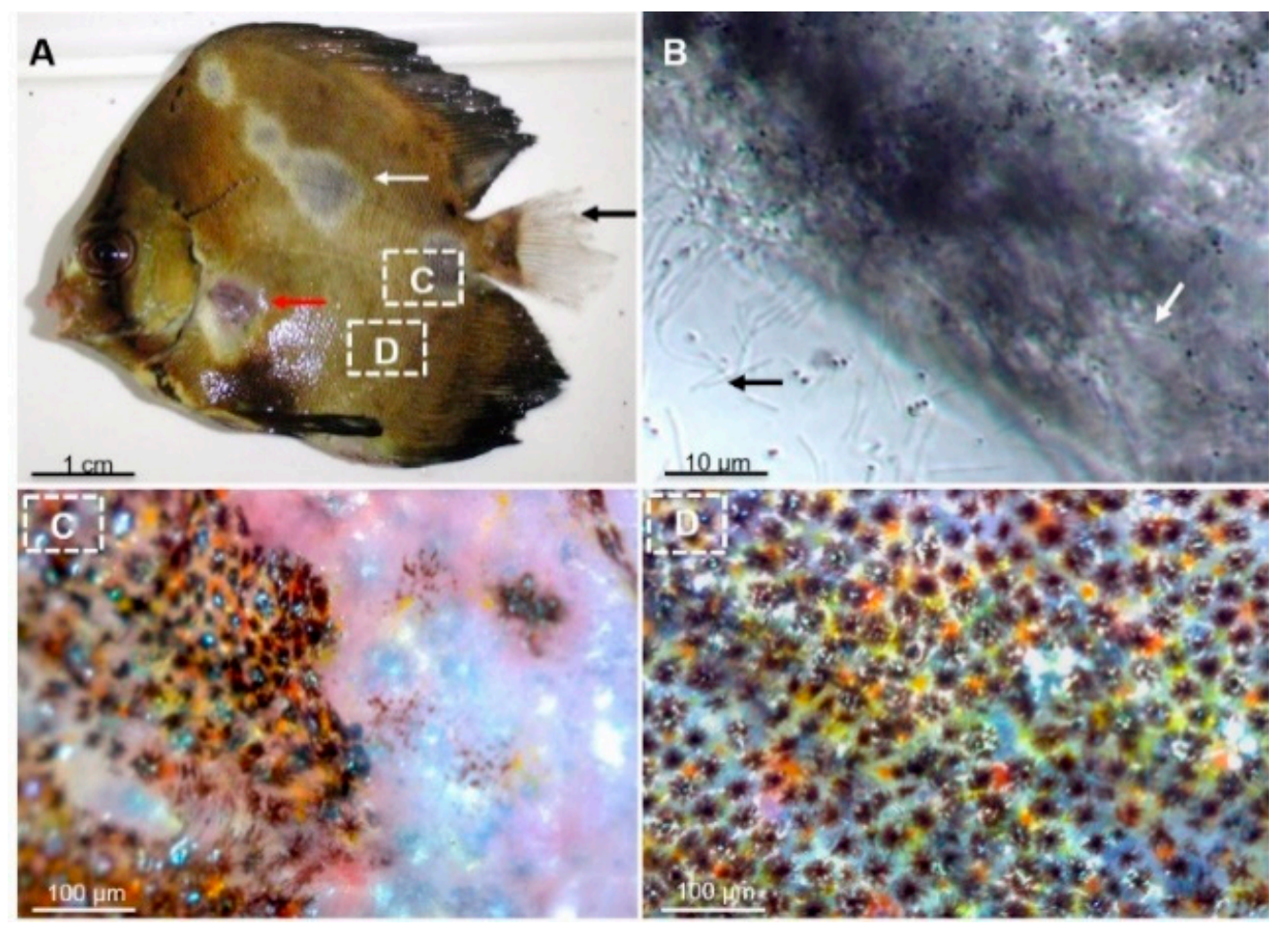

Figure 1. Examination of fish lesions. (A) Gross clinical signs of the 'white-patch disease' of batfish characterised by: (i) circular discoloration areas of various sizes, apparently randomly distributed on the skin surface; (ii) skin lesions, ulcers, scale loss (white arrow) and areas of haemorrhagic necrosis (red arrow); and (iii) frayed (usually caudal) fins (black arrow). (B) Microscopic examination of skin lesions reveals abundant, long, slender, rod-shaped bacteria. Numerous bacteria remained adherent to the fish scales (white arrows) while others detached after the fragment of lesion was crushed (black arrow). (C) View of the skin surface at the interface between apparently healthy and damaged zones. (D) An apparently healthy zone observed under a surgical Q-Scope microscope (AnMo Electronics).

Histopathological examination of skin lesions from moribund batfish revealed that the epidermis and dermis were severely damaged, with clusters of filamentous, Tenacibaculumlike bacteria and scattered inflammatory cells (Figure 2). In contrast, no evidence of histopathological changes was noticed in the internal organs.

Ten bacterial isolates were retrieved from samples of 10 moribund batfish exhibiting typical signs of 'white-patch disease' using Flavobacteriaceae-selective marine agar (Table 1). Two different colony morphotypes were observed after $48 \mathrm{~h}$ of incubation at $27^{\circ} \mathrm{C}$ : the first morphotype consisted of pale, translucent colonies with uneven edges, extremely adherent to the agar (Figure 3A), while the second morphotype consisted of orange, opaque, diffuse and strongly iridescent colonies (Figure 3B,C). 

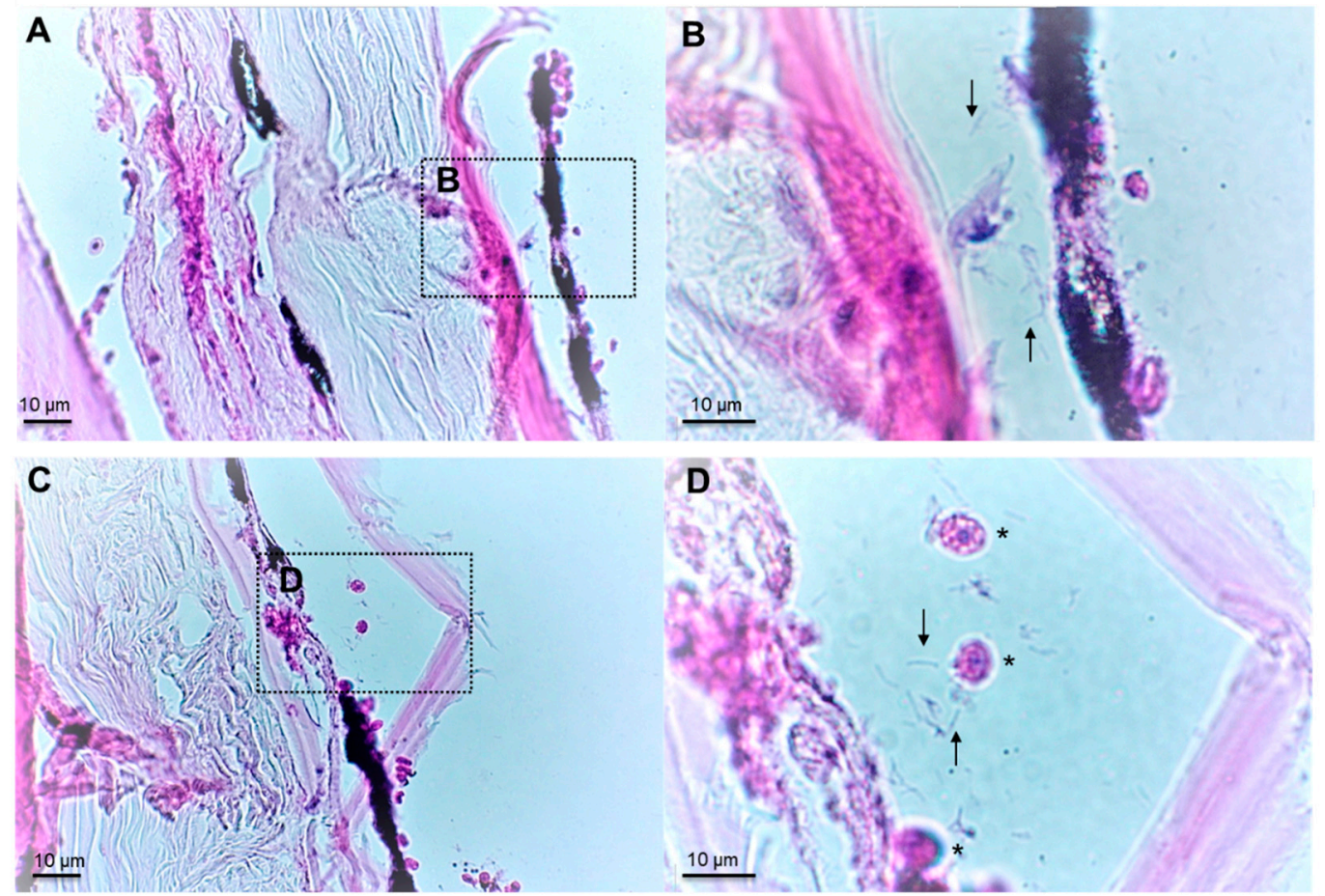

Figure 2. Two representative cross-sections (H-E staining) of Platax orbicularis fingerlings affected by 'white-patch disease'. (A,C): Severe necrosis affecting the hypodermis and dermis layers with invasion of Tenacibaculum-like cells visible at higher magnification (B,D) (arrows) and presence of inflammatory cells in damaged areas (asterisks).
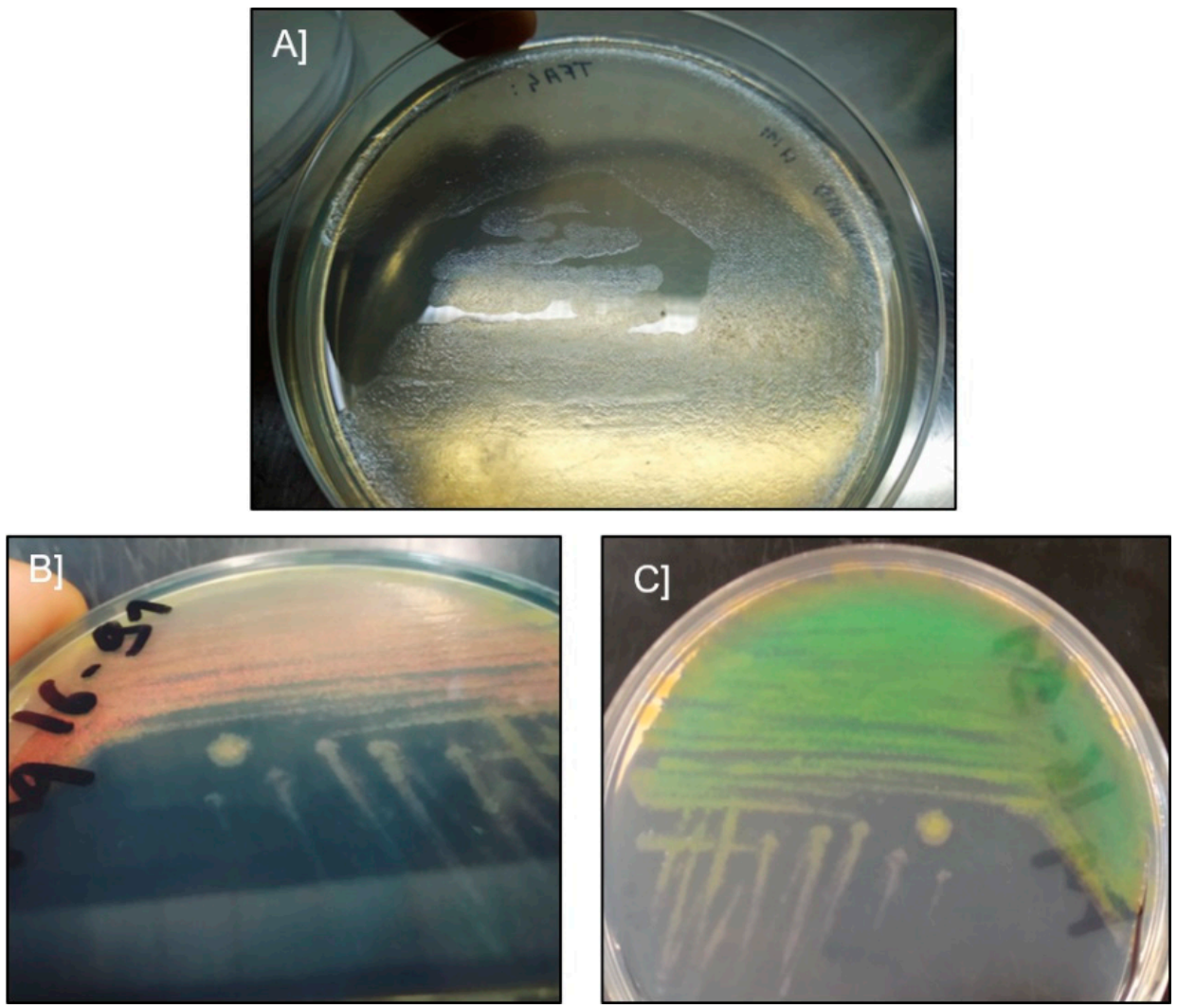

Figure 3. Representative isolates isolated from symptomatic Platax orbicularis. (A) colonies of Tenacibaculum maritimum, isolate TFA4. (B,C) colonies of Tenacibaculum mesophilum, isolate Aq 16-91, with different camera shooting angles revealing the iridescent phenotype. 


\subsection{Genomic and Serological Characterisation}

Analysis of nearly complete $16 \mathrm{~S}$ rRNA sequences revealed that all isolates belonged to the genus Tenacibaculum. Seven isolates (TFA4, Aq 16-83, Aq 16-84, Aq 16-85, Aq 16-87, Aq $16-88$ and Aq 16-89) shared $99.65 \%$ to $99.79 \%$ sequence identity with the T. maritimum type strain NBRC $15946^{\mathrm{T}}$, with at least $98.9 \%$ coverage. The three remaining isolates (Aq 9-66, Aq 9-67 and Aq 16-91) displayed 99.37 to 99.93\% sequence identity with the T. mesophilum type strain DSM $13764^{\mathrm{T}}$, with at least $98.9 \%$ coverage. A tentative phylogenetic tree was drawn using MAFFT (Figure S1). The seven isolates displaying the first morphotype clustered with the T. maritimum type strain, while the three isolates belonging to the second morphotype clustered with the T. mesophilum type strain; bootstrap values were $100 \%$ and $91 \%$, respectively.

The results of the MLSA analysis (Figure 4) performed on T. maritimum isolates TFA4, Aq 16-85, Aq 16-88 and Aq 16-89 showed that none matched exactly with any of the sequence types (ST) already described in the pubMLST database. They were therefore treated as belonging to new STs: ST168, which was attributed to isolate TFA4, and ST167, which was attributed to isolates Aq 16-85, Aq 16-88 and Aq 16-89. Analysis of the number of locus variants revealed that these novel STs only share three allele types (AT), corresponding to loci gyrB, infB and $\mathrm{rlmN}$, which reveal genetic heterogeneity among these two groups of isolates. The single and double locus variant analyses (SLV and DLV) were fairly congruent with the phylogenetic tree based on the concatenated nucleotide sequences of the seven housekeeping genes (Figure 4). SLV analysis showed that ST168 (TFA4) shares 6/7 loci with ST2, which up to now only included strain ACC13.1 (referenced as 002 in the pubMLST database), isolated from a diseased Senegalese sole (Solea senegalensis) in Portugal. In the DLV analysis, TFA4 shared 5/7 loci with ST3, 4, 10, 35, 36 and 130, which essentially comprise isolates from the south of Europe (except for strain 4646, isolated in Australia). Interestingly, isolates Aq 16-85, Aq 16-88 and Aq 16-89 (ST167) formed a singleton, meaning that they displayed at least three different ATs compared with all the strains included in the pubMLST database. These results revealed the existence of at least two genetically distinct groups of T. maritimum isolates in Tahitian fish farms.

Serological analysis revealed two different serogroups among the T. maritimum isolates. Slide agglutination tests showed that strain TFA4 specifically reacted with the anti-O3 antiserum, while strains Aq 16-85, Aq 16-88 and Aq 16-89 specifically reacted with the anti-O1 antiserum.

\subsection{Pathogenicity Assays Using an Immersion Challenge}

All batfish that were experimentally infected with T. maritimum TFA4 using the immersion challenge (IF group) exhibited typical clinical signs of 'white-patch' disease starting from $24 \mathrm{~h}$ post-infection (PI), although no mortality was recorded at this time point (Figure 5). At $30 \mathrm{~h} \mathrm{PI}$, fish in this group underwent significant (chi-squared-test with simulated $p$-value correction, $p=0.017$ ) mortality, with a survival probability of $94.9 \%$ compared with $100 \%$ (no death events) in the non-infected fish group (NIF). A sudden mortality event was observed in the IF group between 30 and $48 \mathrm{~h} \mathrm{PI}$, with $94.9 \%$ and $25 \%$ survival probabilities, respectively. From $82 \mathrm{~h}$ until the end of the monitoring period (120 h PI), no increase in mortality was observed ( $7.1 \%$ survival probability for the IF group at $72 \mathrm{~h}$ PI to $120 \mathrm{~h}$ PI) even though all batfish displayed typical clinical signs of the disease. Nevertheless, the intensity of ulcerative skin lesions (i.e., the number and area of whitish patches) in the IF group from $72 \mathrm{~h}$ to $120 \mathrm{~h}$ PI was lower than that observed before $72 \mathrm{~h}$ PI. In fish from which mucus was partially removed prior to the bath challenge (IM-IF), batfish not only experienced the highest mortality rate (all fish died), giving a survival probability of $0 \%$ from $30 \mathrm{~h} \mathrm{PI}$, but they also died significantly earlier than those of the IF group with intact skin mucus (log-rank test comparing the survival curves from $0 \mathrm{~h}$ PI to $30 \mathrm{~h}$ PI, $p=0.02$ ). No mortality was recorded in the NIF control group during the entire trial. 
Tree scale: 0.001

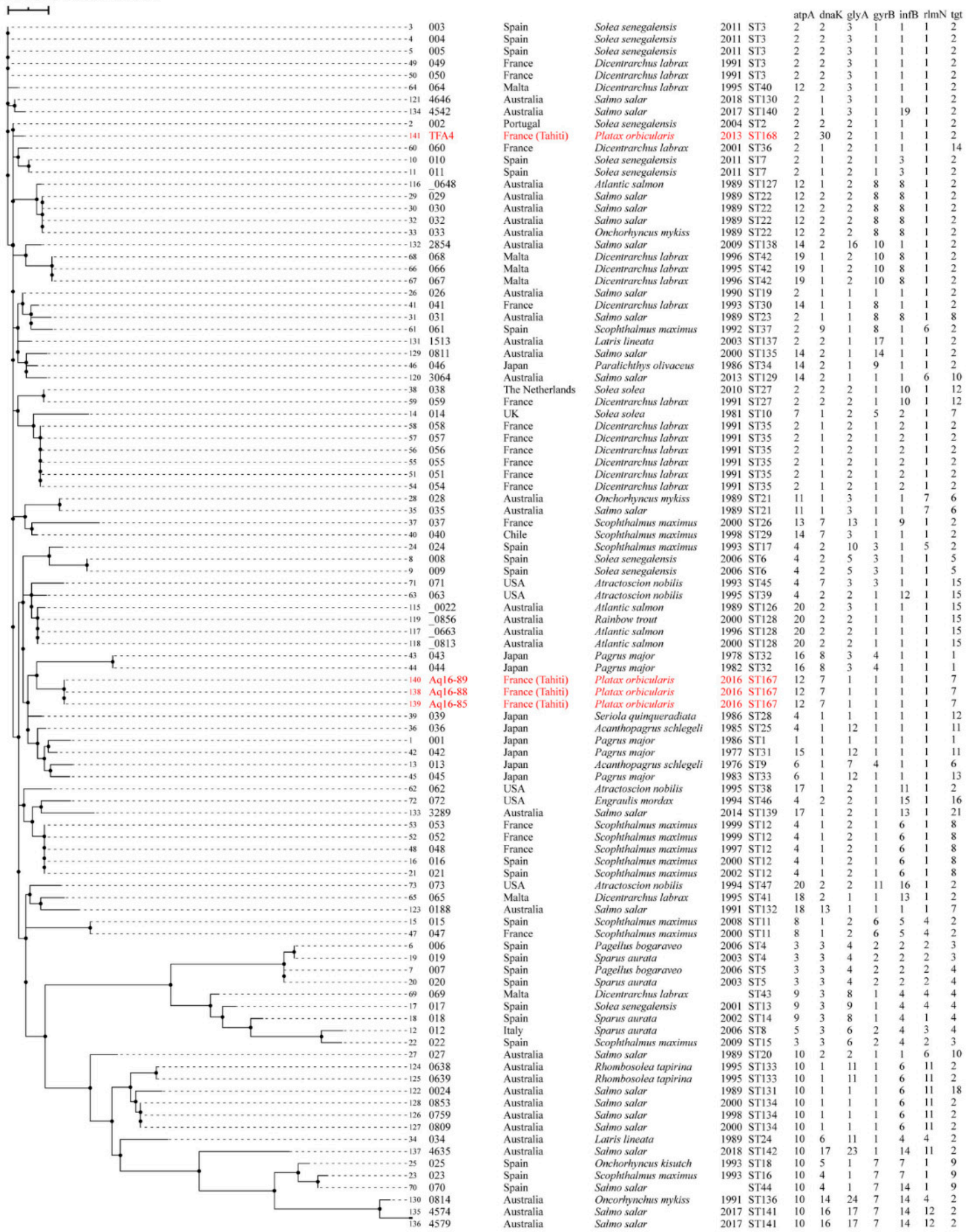

Figure 4. Neighbour-joining tree based on the concatenated nucleotide sequences of 7 housekeeping genes (3894 bp). Isolates isolated in this study are shown in red. Genomic and background information on all T. maritimum isolates in the pubMLST database is included. Other information: strain number, strain name, country of isolation, fish host species, year of isolation, sequence type and allelic combination. 


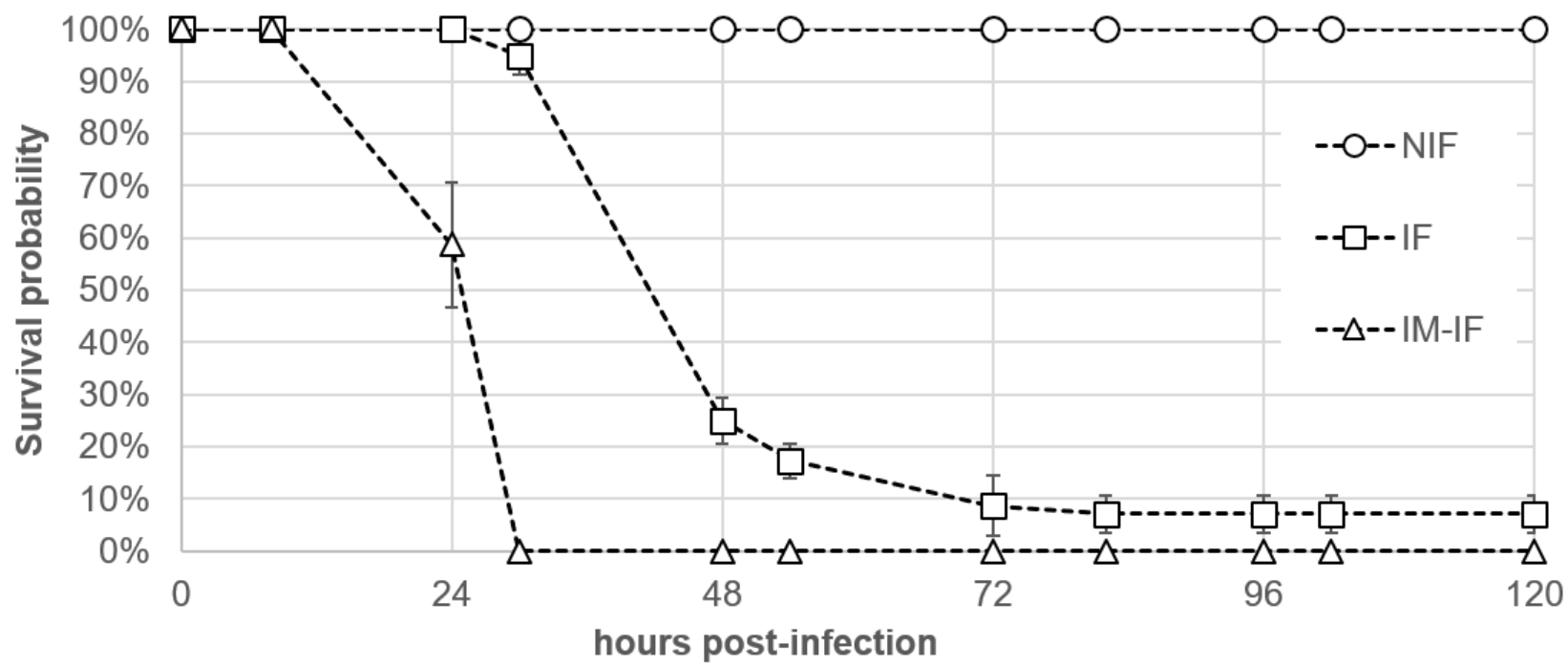

Figure 5. Survival curves of bath-challenged batfish Platax orbicularis. NIF, non-infected fish (triplicate); IF, fish infected with $5.3 \times 10^{4} \mathrm{CFU} \mathrm{mL} \mathrm{mL}^{-1}$ of isolate TFA4 for $2 \mathrm{~h}$ (four replicates); IM-IF, infected fish from which mucus was partially removed prior to the bath challenge (triplicates).

All skin samples that were collected from diseased fish in the IF group before the onset of mortality were found positive by real-time PCR assay, with an average load of $7.8 \times 10^{8} \pm 1.4 \times 10^{8}$ T. maritimum bacteria per $\mu \mathrm{g}$ of total extracted DNA. In contrast, no T. maritimum was detected in any of the four analysed skin samples in the NIF group. The virulence potential of two (Aq 16-84 and Aq 16-87) and three (Aq 9-65, Aq 9-66 and Aq 9-67) isolates belonging to the species T. maritimum and T. mesophilum, respectively, was also evaluated using the same immersion challenge protocol. The results of this separate trial showed that the two T. maritimum isolates exhibited levels of virulence similar to that of isolate TFA4, whereas the three T. mesophilum isolates were avirulent at a similar infection dose $\left(6.1 \times 10^{4} \mathrm{CFU} \mathrm{mL} \mathrm{mL}^{-1}\right)$, with no mortality recorded in groups IF and NIF during a seven-day post-infection survey (data not shown).

\subsection{Kinetics of Tenacibaculum maritimum Infection during a Field Episode of Tenacibaculosis}

In order to gain insight into T. maritimum pathogenesis under natural field conditions, a batch of batfish was monitored from its production under bio-secured conditions at the VAIA hatchery to its rearing in a net cage on a private farm in Tautira lagoon. Soon after the transfer to the net cage in the lagoon, a severe outbreak of 'white-patch disease' was observed, with the first typical signs appearing from D1 post-transfer and mortality from D3 (Figure 6).

Two peaks of mortality occurred, at D3-D6 and D13-D31. The second peak was higher, with cumulative mortalities increasing significantly from $11.2 \%$ at D13 to $74.5 \%$ at D31. No subsequent mortality occurred among the surviving batfish until the end of the study period (D36). Six days before the transfer to the lagoon cage (D-6), all sampled fish were qPCR negative for T. maritimum (Figure 7).

In contrast, the mucus of all batfish sampled just one day (D1) after the transfer to the lagoon net cages was found positive for T. maritimum by qPCR, although very different bacterial loads (mean values, $9.98 \times 10^{6} \pm 1.57 \times 10^{7}$ cells per $\mu$ g DNA) were observed. At D9, during the first stationary phase of mortality (D6-D13), asymptomatic batfish showed significantly lower bacterial loads in their mucus compared with D1 (Kruskal Wallis test; $p=0.020$ ). Nevertheless, the amount of T. maritimum at D9 was significantly higher $(p=0.047)$ in batfish exhibiting clinical signs of tenacibaculosis compared with asymptomatic fish. During the second peak of mortality, the discrepancy between asymptomatic and symptomatic batfish was even more pronounced $(p=0.016)$. At the end of the mortality events (D36), T. maritimum DNA was absent from most surviving fish sampled 
$(8 / 10)$. Indeed, only two asymptomatic batfish among the 10 tested were found positive by qPCR but at very low levels $\left(8.36 \times 10^{2} \pm 6.02 \times 10^{2}\right.$ cells per $\left.\mu \mathrm{g} D N A\right)$, signalling the end of the outbreak.

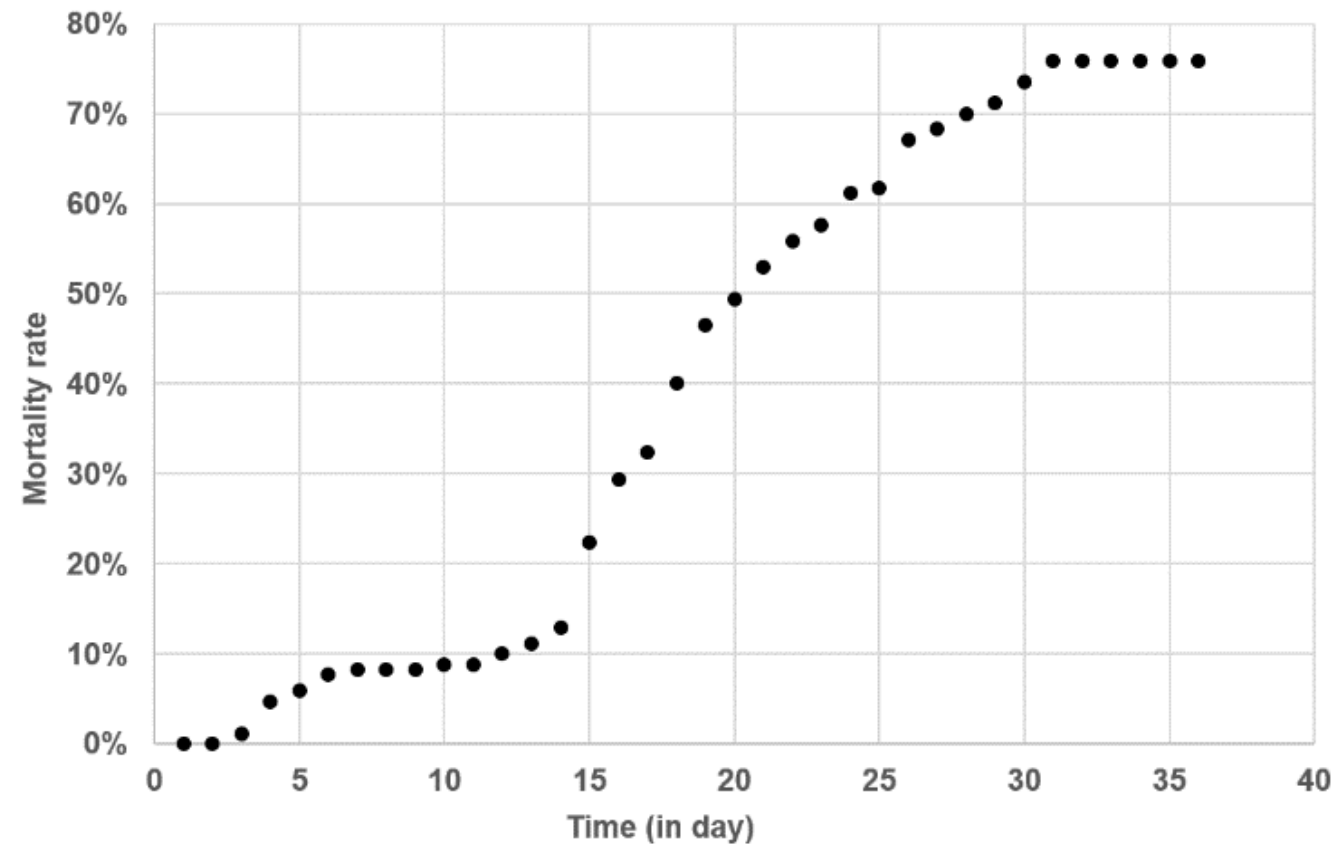

Figure 6. Cumulative mortalities of a batch of batfish during a natural outbreak following their transfer to a net cage in Tautira lagoon. Fish were $10 \mathrm{~g}$ (mean weight) and reared at an initial density (D0) of $167 \mathrm{fish} / \mathrm{m}^{3}$.

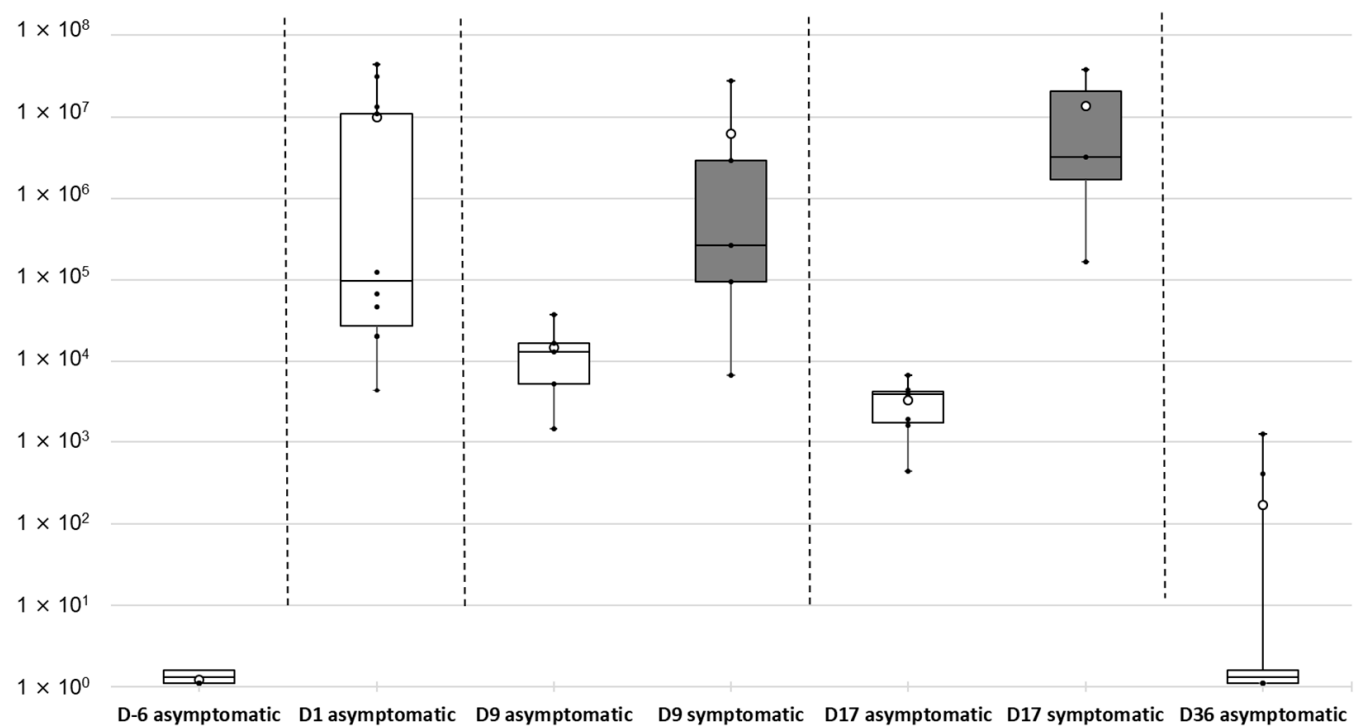

Figure 7. Kinetics of Tenacibaculum maritimum bacterial cells quantified by qPCR in the mucus of asymptomatic (white boxes) and symptomatic (grey boxes) batfish from D-6 (at VAIA hatchery) to D36 post-transfer to net cage in the lagoon. Quantification results are expressed in numbers of T. maritimum cells per $\mu \mathrm{g}$ of total extracted gDNA. Because zero values (no detection) cannot be represented on a logarithmic scale, an arbitrary value of 1.1 was assigned to these negative results. Each box-plot shows mean (white circle), the 25th to 75th percentile (rectangular box), the minimum and maximum values (dots at the extremities), as well as individual quantification (black dots) from 5 to 10 batfish per sampling time and group of batfish. 
qPCR results on the liver of the same batfish sampled for their mucus revealed that only one fish among the 50 tested, sampled at D1, was positive for T. maritimum at a low level $\left(1.19 \times 10^{4}\right.$ cells per $\mu \mathrm{g}$ gDNA). Similar results were obtained with the posterior intestine: only seven batfish were found $\mathrm{GPCR}$ positive, with the low value of $1.11 \times 10^{4} \pm 1.37 \times 10^{4}$ cells per $\mu \mathrm{g}$ gDNA.

\section{Discussion}

Orbicular batfish aquaculture in French Polynesia started in 2004, and the first symptoms of 'white-patch' disease were observed in 2006. In this study, we showed that the 'white-patch disease' decimating farmed Platax orbicularis is associated with T. maritimum infection. To our knowledge, this is the first time that this bacterium has been isolated in French Polynesia and also the first time it has been retrieved from batfish. T. maritimum has been associated with a large variety of marine fish species: 38 according to Nowlan et al. (2020) [5], including the orbicular batfish (this study). Surprisingly, Platax orbicularis is the only tropical fish in which this pathogen has been reported so far. Nevertheless, the range of susceptible hosts for this bacterium is probably underestimated. In French Polynesia, tenacibaculosis has dramatic consequences for batfish farms, which often suffer mortality levels over $50 \%$. In addition, the disease may also be of serious concern regarding the diversification of aquaculture programs launched by local authorities.

In this study, we described a reproducible bath challenge protocol that demonstrated that T. maritimum is able to infect orbicular batfish by immersion, thus fulfilling Koch's postulates. Experimental infection procedures using immersion challenges have been broadly used with fish pathogens in recent years because they are likely to mimic the natural infection process more accurately than injection challenges. In particular, immersion does not bypass the first line of fish defence (i.e., the skin mucus barrier), unlike the more common subcutaneous, intraperitoneal and intramuscular injection routes. It was also reported that, compared with immersion, some injection challenges fail to induce tenacibaculosis [11,19-21] or can lead to high mortality rates in negative controls due to stress and local lesions caused by the injection [22]. However, comparative analyses of challenge protocols are rather difficult to perform due to the many factors reported influencing pathogenicities, such as the bacterial strain $[9,20,21]$, culture conditions (i.e., growth medium and temperature), infection dose [12,19], duration of immersion [23], physical [21] and chemical characteristics of seawater, zootechnical practices (e.g., fish density and animal feed), the host fish species [8], physiological status (e.g., age [21]) and genetic background (e.g., susceptible, resistant). In this study, no significant difference in mortality rates was observed when batfish were infected with isolates TFA4, Aq 16-87, or Aq 16-84, although these isolates differed in some genetic traits. However, due to the high virulence of these isolates in our immersion challenge model, further studies using a lower dose or shorter immersion time might reveal virulence differences between these strains. Although physical alteration of the fish skin was not necessarily noticed before morbidity and mortality, batfish with impaired mucus developed clinical signs more rapidly and experienced higher mortality rates (100\% mortality at $23 \mathrm{~h}$ post infection) than those where mucus was intact. These results are in agreement with similar studies performed on other fish species [11,23]. Indeed, mucus has been largely documented as an important component of the fish innate immune system and a physical and chemical barrier against pathogens [24].

Some of the isolates from diseased batfish were shown to belong to another Tenacibaculum species, T. mesophilum, a bacterium initially retrieved from a marine sponge. In addition, T. mesophilum strain HMG1 was shown to degrade malachite green, an antimicrobial that has long been used in aquaculture but is now banned in many countries [25]. Immersion challenges performed with isolates Aq 9-66 and Aq 9-67 showed that both strains were totally avirulent. Further studies would be needed, however, to determine whether T. mesophilum isolates can play a role in the pathogenesis of tenacibaculosis, primarily caused by T. maritimum, by acting as secondary colonisers of the lesions. 
Although this study was conducted with only 10 isolates, an unexpected diversity of T. maritimum isolates was found. Our results demonstrate the presence of two distinct groups: isolates Aq 16-85, Aq 16-88 and Aq 16-89, belonging to serotype O1 and to sequence type ST167; and isolate TFA4, belonging to serotype O3 and to sequence type ST168. Such diversity among T. maritimum isolates was also noticed among Australian isolates (Figure 4). In agreement with Van Gelderen et al. (2010) [26], no correlation between serotype and geographic distribution was observed in the present study. In contrast with some authors $[27,28]$ who reported a correlation between the host and the serotype of T. maritimum, our results are more consistent with other studies $[9,26,29]$ that revealed that several different serotypes could be found associated with the same fish species.

Table 1. List of bacterial isolates retrieved from farmed Platax orbicularis affected by 'white-patch' disease, with their sources and characteristics. Virulence was evaluated by experimental bath challenge on T. maritimum-free batfish. Significant differences $(p<0.05)$ in mortality rate (see paragraph 3-3) between non-infected and infected fish are indicated by 'yes' or 'no'. Isolate identification was performed using the EzBioCloud software [30], based on $>99 \%$ identity of their $16 \mathrm{~S}$ rRNA sequences with the closest type strain. ST refers to the MLST sequence type. n/a: not analysed.

\begin{tabular}{|c|c|c|c|c|c|c|}
\hline Isolate & $\begin{array}{c}\text { Source and Date } \\
\text { of Isolation }\end{array}$ & GPS Location & $\begin{array}{c}\text { 16S rDNA GenBank } \\
\text { Accession Number }\end{array}$ & $\begin{array}{l}\text { Bacterial } \\
\text { Species }\end{array}$ & Virulence & ST \\
\hline TFA4 & $\begin{array}{l}\text { Skin lesions, } \\
\text { Tautira lagoon, } \\
\text { Tahiti, } 2013\end{array}$ & $\begin{array}{c}17^{\circ} 47^{\prime} 50^{\prime \prime} \mathrm{S} \\
149^{\circ} 07^{\prime} 14^{\prime \prime} \mathrm{W}\end{array}$ & MW690171 & T. maritimum & yes & ST168 \\
\hline Aq 9-66 & $\begin{array}{c}\text { Skin lesions, } \\
\text { Tautira lagoon, } \\
\text { Tahiti, } 2013\end{array}$ & $\begin{array}{c}17^{\circ} 47^{\prime} 50^{\prime \prime} \mathrm{S} \\
149^{\circ} 07^{\prime} 14^{\prime \prime} \mathrm{W}\end{array}$ & MW690177 & T. mesophilum & no & \\
\hline Aq 9-67 & $\begin{array}{c}\text { Skin lesions, } \\
\text { Tautira lagoon, } \\
\text { Tahiti, } 2013\end{array}$ & $\begin{array}{c}17^{\circ} 47^{\prime} 50^{\prime \prime} \mathrm{S}, \\
149^{\circ} 07^{\prime} 14^{\prime \prime} \mathrm{W}\end{array}$ & MW690178 & T. mesophilum & no & \\
\hline Aq 16-83 & $\begin{array}{c}\text { Skin lesions, } \\
\text { Vairao lagoon, } \\
\text { Tahiti, } 2016\end{array}$ & $\begin{array}{c}17^{\circ} 48^{\prime} 22^{\prime \prime} \mathrm{S}, \\
149^{\circ} 17^{\prime} 36^{\prime \prime} \mathrm{W}\end{array}$ & MW690172 & T. maritimum & $\mathrm{n} / \mathrm{a}$ & $\mathrm{n} / \mathrm{a}$ \\
\hline Aq 16-84 & $\begin{array}{c}\text { Skin lesions, } \\
\text { Vairao lagoon, } \\
\text { Tahiti, } 2016\end{array}$ & $\begin{array}{c}17^{\circ} 48^{\prime} 22^{\prime \prime} \mathrm{S}, \\
149^{\circ} 17^{\prime} 36^{\prime \prime} \mathrm{W}\end{array}$ & MW690173 & T. maritimum & yes & $\mathrm{n} / \mathrm{a}$ \\
\hline Aq 16-85 & $\begin{array}{c}\text { Skin lesions, } \\
\text { Vairao lagoon, } \\
\text { Tahiti, } 2016\end{array}$ & $\begin{array}{c}17^{\circ} 48^{\prime} 22^{\prime \prime} \mathrm{S}, \\
149^{\circ} 17^{\prime} 36^{\prime \prime} \mathrm{W}\end{array}$ & MW690174 & T. maritimum & $\mathrm{n} / \mathrm{a}$ & ST167 \\
\hline Aq 16-87 & $\begin{array}{c}\text { Skin lesions, } \\
\text { Vairao lagoon, } \\
\text { Tahiti, } 2016\end{array}$ & $\begin{array}{c}17^{\circ} 48^{\prime} 22^{\prime \prime} \mathrm{S} \\
149^{\circ} 17^{\prime} 36^{\prime \prime} \mathrm{W}\end{array}$ & MW690175 & T. maritimum & yes & $\mathrm{n} / \mathrm{a}$ \\
\hline Aq 16-88 & $\begin{array}{l}\text { Skin lesions, } \\
\text { Vairao lagoon, } \\
\text { Tahiti, } 2016\end{array}$ & $\begin{array}{c}17^{\circ} 48^{\prime} 22^{\prime \prime} \mathrm{S} \\
149^{\circ} 17^{\prime} 36^{\prime \prime} \mathrm{W}\end{array}$ & MW690176 & T. maritimum & $\mathrm{n} / \mathrm{a}$ & ST167 \\
\hline Aq 16-89 & $\begin{array}{l}\text { Skin lesions, } \\
\text { Vairao lagoon, } \\
\text { Tahiti, } 2016\end{array}$ & $\begin{array}{c}17^{\circ} 48^{\prime} 22^{\prime \prime} \mathrm{S} \\
149^{\circ} 17^{\prime} 36^{\prime \prime} \mathrm{W}\end{array}$ & MW690180 & T. maritimum & $\mathrm{n} / \mathrm{a}$ & ST167 \\
\hline Aq 16-91 & $\begin{array}{c}\text { Skin lesions, } \\
\text { Vairao lagoon, } \\
\text { Tahiti, } 2016\end{array}$ & $\begin{array}{c}17^{\circ} 48^{\prime} 22^{\prime \prime} \mathrm{S}, \\
149^{\circ} 17^{\prime} 36^{\prime \prime} \mathrm{W}\end{array}$ & MW690179 & T. mesophilum & $\mathrm{n} / \mathrm{a}$ & \\
\hline
\end{tabular}

Additional work is needed for an in-depth exploration of the genetic diversity of Tenacibaculum isolates associated with batfish in French Polynesia in order to evaluate their virulence potential and develop management and disease control strategies. Because the natural ecology of T. maritimum is still unknown, more in-depth epidemiological studies will also be necessary to decipher the mode of transmission and the natural route of infection of this pathogen. 


\section{Materials and Methods}

\subsection{Sampling of Diseased Fish}

Ten symptomatic orbicular batfish (mean weight $5.1 \pm 2.3 \mathrm{~g}$, crop density of $170 \mathrm{fish} / \mathrm{m}^{3}$ ) were collected from two different farms located in Tahiti island. Fish were transported alive in the microbiology laboratory, using buckets filled with seawater and protected from direct sunlight for further examination. They were sampled during two severe outbreaks in 2013 and 2016 that had caused $>50 \%$ cumulative mortality just 2 weeks after the fish had been transferred from the VAIA hatchery to net cages in the Tahiti lagoon. The sea temperature was $26.5^{\circ} \mathrm{C}$ in 2013 and $27^{\circ} \mathrm{C}$ in 2016 , and water salinity was consistently $3.3 \%$. All fish showed erosion and ulceration of the skin surface. After being euthanised with an overdose of Benzocaine (150 $\mathrm{mg} \mathrm{L}^{-1}$ ), they were examined by microscopy and microbiological and histological techniques. This method of euthanasia, reproducible and safe to the operator, induces a depression of the central nervous system activity, rapid unconsciousness and death of $P$. orbicularis, without compromising further diagnostic techniques.

\subsection{Direct Microscopic Examination and Isolation of Bacteria}

Skin lesion scrapings from moribund batfish were performed using sterile surgical scalpels. Wet mount preparations of these samples were then examined under a light microscope (Leica DM 1000 LED). For bacterial isolation, a sterile swab cotton-tipped applicator (COPAN) was used. Smears of skin samples were deposited onto plates of Flavobacteriaceae-selective marine agar (FSMA) developed by an accredited veterinary diagnostic laboratory (Labofarm, Loudéac, France). A total of ten dominant bacterial isolates were isolated after sub-culture (Table 1). Bacterial isolates were cryo-conserved at $-80{ }^{\circ} \mathrm{C}$ in Marine Broth medium supplemented with $15 \%$ of glycerol.

\subsection{Histopathological Examination}

Skin fragments of approximately $1 \mathrm{~cm}^{2}$, as well as internal organs (anterior kidney, spleen, liver), were collected from four fish showing typical skin lesions of 'whitepatch' disease using a sterile surgical scalpel. Samples were fixed in Davidson's solution ( $25 \%$ formaldehyde, $37.5 \%$ ethanol, $12.5 \%$ acetic acid and $25 \%$ water) for $48 \mathrm{~h}$ at room temperature, then washed and kept in 70\% ethanol [31]. Skin samples were progressively dehydrated in an ascending series of alcohol (70 to 100\% ethanol) followed by a xylene bath, using dehydration automate (Leica, ASP 300S), then embedded in paraffin, cut into $3 \mu \mathrm{m}$ sections using a rotary microtome (Microm HM 340E, Thermo Fisher Scientific, Waltham, MA, USA) and stained with haematoxylin-eosin (H-E) using a fully-automated integrated stainer (Leica, CV5030 autostainer XL). Several sections were analysed to ensure reproducibility, using a Leica DM 1000 LED microscope equipped with a Dino-Lite camera (AnMo Electronics).

\subsection{Molecular and Serological Studies}

The $16 \mathrm{~S}$ rDNA sequences were PCR-amplified using the universal $27 \mathrm{~F}$ and $1492 \mathrm{R}$ primers (Table S1) on $5 \mu \mathrm{L}$ of a boiled bacterial colony. Briefly, a bacterial colony was resuspended in $100 \mu \mathrm{L}$ of molecular-free DNA water, heated 10 minutes at $98{ }^{\circ} \mathrm{C}$ and used immediately as a DNA template. The purity and length of the amplicons were verified by agarose gel electrophoresis. Amplicons were Sanger sequenced by GATCbiotech (https: / / eurofinsgenomics.eu/, accessed 20 January 2021) using the six universal sequencing primers listed in Table $\mathrm{S} 1$.

For each isolate, the six sequences were visualised and aligned to create a consensus sequence (with $>2 \times$ coverage over $80 \%$ of the sequences) using the Benchling software (2020). For primary taxonomic assignation, the 16S rRNA consensus sequences were searched against the EzBioCloud database [21] (accession numbers are given in Table S2). In addition, a tentative phylogenetic tree was constructed using the MAFFT online service [32]. The evolutionary distance was calculated using 1000 bootstrap replicates (Figure S1). 
In order to characterise the genetic diversity of presumptive T. maritimum isolates in greater depth, multi-locus sequence analysis (MLSA) was performed on four selected isolates (TFA4, Aq 16-85, Aq 16-88, Aq 16-89) using sequences retrieved from their draft genomes [18]. These isolates were selected according to their background information: Aq 16-85, Aq 16-88 and Aq 16-89 were sampled from three different infected fish during an outbreak at the Vairao fish farm in 2016, while isolate TFA4 was isolated from a symptomatic fish at the Tautira fish farm in 2013 (Table 1). The MLSA profile defined by Habib et al. (2014) [33] consists of the sequences of seven housekeeping genes (atpA, gyrB, dnaK, gly $A$, $\operatorname{infB}, r \operatorname{lm} N$ and $t g t$ ). The profiles of the new allele and sequence types (ATs and STs, respectively) were generated and analysed using the Tenacibaculum pubMLST database (https:/ / pubmlst.org/tenacibaculum/, accessed on 10 December 2021) [34]. Results were visualised using the incremented Interactive Tree of Life (iTOL) v3 tool [35].

In order to characterise the isolates identified as T. maritimum more precisely, their serotype was determined as described by Avendaño-Herrera et al. (2004) [36]. This method uses a slide agglutination test and a dot blot assay on both whole-cell preparations and heat-stable $\mathrm{O}$ antigens of each strain. Antisera against serovars O1 (PC503.1), O2 (PC424.1) and $\mathrm{O} 3$ (ACC13.1) were used in all assays.

\subsection{Experimental Infection by Immersion and Quantification of Tenacibaculum maritimum in Mucus Samples by Real-Time qPCR}

A batch of Platax orbicularis fingerlings (mean weight $9.7 \pm 2.6 \mathrm{~g}$ ) reared at the VAIA bio-secured hatchery was transferred for acclimatisation to a $1 \mathrm{~m}^{3}$ fibreglass tank containing seawater (salinity, 32 PPT; water temperature, $26-27^{\circ} \mathrm{C}$ ) for 10 days. Prior to infection, 494 fish were randomly selected and transferred to ten $150 \mathrm{~L}$ tanks (49 to 50 fish per tank) filled with $5 \mu \mathrm{m}$ filtered seawater. Three groups were tested in three or four replicates according to the condition: (i) non-infected fish (NIF), (ii) fish infected with T. maritimum isolate TFA4 (IF) and (iii) fish with impaired mucus (IM) infected with T. maritimum isolate TFA4 (IM-IF). The mucus of the latter fish was partially removed by gently wiping one side of the fish with a sponge soaked in filtered seawater. Fish were challenged with a pure culture of isolate TFA 4 obtained by incubation at $27^{\circ} \mathrm{C}$ for $48 \mathrm{~h}$ (stationary phase as determined by preliminary growth monitoring assays using ten-fold serial dilutions) in autoclaved nutrient broth composed of $4 \mathrm{~g} \mathrm{~L}^{-1}$ peptone and $1 \mathrm{~g} \mathrm{~L}^{-1}$ yeast extract (Becton, Dickinson and Co., Sparks, MD, USA) in $5 \mu \mathrm{m}$ filtered seawater under orbital shaking at $200 \mathrm{rpm}$. Bath challenges were performed for two hours with isolate TFA4 at a final concentration of $5.3 \times 10^{4} \mathrm{CFU} \mathrm{mL}^{-1}$ for groups IF and IM-IF or with nutrient broth in the case of the mock-treated NIF control group. The infected fish were then rinsed twice with filtered seawater to remove all non-adherent bacteria, and fish from the NIF control group were manipulated in the same way. Mortality was monitored twice daily from day 0 (D0) until day 5 (D5), at which point the fish were euthanised using 150 $\mathrm{mg} \mathrm{L}^{-1}$ Benzocaine. Any fish that died or were found moribund over the experimental period (D0-D5) were promptly removed from the tanks during the monitoring. The nonparametric Kaplan-Meier method ( $\mathrm{R}$ package survival) was used to test for differential survival performances among groups at the same date or within groups throughout the sampling period. Differences were considered significant at $p<0.05$.

At $24 \mathrm{~h}$ post-infection, before the onset of mortality, four fish displaying skin lesions were randomly sampled from the two infected groups (IF and IM-IF) in addition to four fish from the NIF group. These were used to quantify T. maritimum cells in fish mucus using TAQMAN real-time PCR (see primers and probe in suppl. Table 1) following the protocol developed by Fringuelli et al. (2012) [37] with minor modifications. Briefly, skin mucus samples were obtained from lesions on symptomatic fish using cotton swabs (COPAN), directly diluted in $1.5 \mathrm{~mL}$ microcentrifuge tubes containing $0.5 \mathrm{~mL}$ of lysis solution $(100 \mathrm{mM} \mathrm{NaCl}$, $10 \mathrm{mM}$ Tris $\mathrm{pH} \mathrm{8,} 25 \mathrm{mM}$ EDTA, 0.5\% SDS and $200 \mu \mathrm{g} \mathrm{ml} \mathrm{m}^{-1}$ proteinase $\mathrm{K}$ ) and incubated overnight at $55^{\circ} \mathrm{C}$. DNA was extracted using the conventional phenol/chloroform/isoamyl alcohol (25/24/1) method. DNA quantity and purity were assessed using a NanoDrop ND 
1000 spectrophotometer (Thermo Fisher Scientific). In order to obtain a standard curve, bacterial cells of isolate TFA4 from a stationary phase culture in nutrient broth were enumerated using a Malassez counting chamber $\left(2.35 \times 10^{8}\right.$ bacteria $\left.\mathrm{ml}^{-1}\right)$, and DNA from $1 \mathrm{ml}$ of the bacterial suspension was extracted. The DNA was then spiked at a final concentration of $1.33 \mathrm{ng} \mu \mathrm{L}^{-1}$ in salmon sperm gDNA (SSD, Thermo Fisher) at $10 \mathrm{ng} \mu \mathrm{L}^{-1}$ in artificial seawater (ASW, Sigma), then serially diluted 10 -fold in SSD at $10 \mathrm{ng} \mathrm{L}^{-1}$ in ASW. A linear range of values was obtained for PCR amplification on an Mx3000 Thermocycler (Agilent) using Brilliant III Ultra-Fast QPCR Master Mix (Agilent) following the supplier's recommendations ( $5 \mu \mathrm{L}$ DNA at $10 \mathrm{ng} \mu \mathrm{L}^{-1}$ in a total reaction volume of $20 \mu \mathrm{L}$ ), with six successive sample 10-fold dilutions tested in triplicate. Cycle threshold $(\mathrm{Ct})$ values ranged from 16.05 to 33.14 , corresponding to $1.44 \times 10^{5}$ to $2.06 \times 10^{1}$ cells of isolate TFA4 per PCR well, while correlation (linear regression with $\mathrm{r}^{2}$ coefficient) and qPCR reaction efficacy were 0.995 and $99.9 \%$, respectively.

\subsection{Detection and Quantification of Tenacibaculum maritimum during a Field Episode of Tenacibaculosis}

Juvenile batfish (mean weight $10 \pm 3.3 \mathrm{~g}$ ) reared in the bio-secure facilities of the VAIA hatchery were carefully transferred (D0) to the Tahiti Fish Aquaculture farm in Tautira lagoon and kept in a single net cage of $1 \mathrm{~m}^{3}$ (167 fish $/ \mathrm{m}^{3}$ density). Ten fish were collected at five sampling times: day 6 before transfer (D-6) (i.e., in the VAIA hatchery) and D1, D9, D17 and D36 post-transfer to Tautira lagoon. When gross signs of 'white-patch disease' were observed, five moribund fish (symptomatic) and five apparently healthy (asymptomatic) ones were sampled. These fish were euthanised as detailed above, and the liver, posterior intestine and some skin mucus (collected with a cotton swab in the lesion area in the case of symptomatic fish) were individually and aseptically sampled and preserved in $500 \mu \mathrm{L}$ RNAlater (Ambion) at $-80^{\circ} \mathrm{C}$. Approximately $100 \mathrm{mg}$ of tissue were used to quantify T. maritimum by qPCR [37]. Throughout this survey, no curative treatments were given, mortality was monitored daily, and moribund animals (euthanatised with an overdose of benzocaine) or dead fish were removed and discarded.

Supplementary Materials: The following are available online at: https:/ /www.mdpi.com/article/ 10.3390/pathogens11020131/s1, Figure S1: Phylogenetic relationships of 16S rDNA nucleotide sequences of the isolates recovered in this study and the type strains of all Tenacibaculum species (See Table S2 for accession number); Table S1: List of PCR primers and probe used in this study; Table S2: Accession number of the type strains used in Figure S1.

Author Contributions: Conceptualisation, D.S. and R.D.; Methodology, C.B. (Corinne Belliard), C.B. (Caline Basset), S.S.-G., A.M. and C.L.; software, P.L. and V.L.; Validation, D.S. and E.D.; Formal Analysis, R.T., V.L., D.S. and P.L.; Investigation, D.S., S.S.-G. and R.T.; Resource, J.F.B., R.D. and D.S., Data Curation, D.S. and R.D.; writing—original draft preparation, P.L. and D.S.; writing—review and editing, P.L., D.S., E.D. and J.F.B.; supervision, D.S. and E.D.; project administration, R.D. and D.S.; Funding Acquisition, D.S. and R.D. All authors have read and agreed to the published version of the manuscript.

Funding: This work was supported by IFREMER and the Direction des Ressources Marines through "Aqua-Sana 1 and Aqua-Sana2" collaborative projects (2016-2021) and by the Ministère de l'Economie Verte et du Domaine en charge des Mines et de la Recherche de Polynésie Française through « Tenacifight » project (2020-2022). P. Lopez was granted an IFREMER-DRM scholarship.

Institutional Review Board Statement: Animal experiments and sampling were performed in accordance with the sections of deliberation no 2001-16 APF from the Assembly of French Polynesia issued in Journal Officiel de Polynésie française on 1 February 2001 dealing on domestic or wild animals welfare and were carried out under the supervision of the Direction des Ressources Marines de Polynésie Française (Direction des Ressources Marines, Fare Ute Immeuble Le caill, BP 20-98713 Papeete, Tahiti, Polynésie française) following the European Commission DGXI [38] and ARRIVE [39] guidelines.

Informed Consent Statement: Not applicable.

Data Availability Statement: Data are contained within the article or Supplementary Material. 


\begin{abstract}
Acknowledgments: The authors are indebted to Alicia Estévez Toranzo (Universidad de Santiago de Compostela, Spain) for serotyping the T. maritimum batfish isolates. We are also grateful to Sylvain Dupieux and Eddy Laille of Tahiti Fish Aquaculture company, Edouard Lehartel from Tautira Aquaculture company, and Benoît Le Marechal, Director of Cooperative des Aquaculteurs de Polynésie française (CAPF) as well as his colleagues Wallen Teiri, Heifara Wallon and Sylvain Dupieux, who provided us with the experimental fish used in this study. We would also like to thank the Bureau de Traduction de l'Université, UBO, Brest, for revising the English of the manuscript.
\end{abstract}

Conflicts of Interest: Labofarm from the Finalab Veterinary Laboratory Group provided support in the form of salary for AM but did not have any additional role in the design of the study; in the collection, analyses, or interpretation of data; in the writing of the manuscript, or in the decision to publish the result. The specific roles of this author are indicated in the 'author contributions' section.

\title{
References
}

1. Nakabo, T. Fishes of the Japan: With Pictorial Keys to the Species, English Edition; Tokai University Press: Tokyo, Japan, 2002; ISBN 978-4-486-01570-3.

2. Barros, B.; Sakai, Y.; Hashimoto, H.; Gushima, K. Feeding behavior of leaf-like juveniles of the round batfish Platax orbicularis (Ephippidae) on reefs of Kuchierabu-jima Island, southern Japan. J. Ethol. 2008, 26, 287-293. [CrossRef]

3. Andréfouët, S.; Adjeroud, M. French Polynesia. In World Seas: An Environmental Evaluation; Elsevier: Amsterdam, The Netherlands, 2019; pp. 593-618, ISBN 978-0-08-100853-9.

4. Suzuki, M.; Nakagawa, Y.; Harayama, S.; Yamamoto, S. Phylogenetic analysis and taxonomic study of marine Cytophaga-like bacteria: Proposal for Tenacibaculum gen. nov. with Tenacibaculum maritimum comb. nov. and Tenacibaculum ovolyticum comb. nov., and description of Tenacibaculum mesophilum sp. nov. and Tenacibaculum amylolyticum sp. nov. Int. J. Syst. Evol. Microbiol. 2001, 51, 1639-1652. [CrossRef]

5. Nowlan, J.P.; Lumsden, J.S.; Russell, S. Advancements in Characterizing Tenacibaculum Infections in Canada. Pathogens 2020, 9, 1029. [CrossRef]

6. Masumura, K.; Wakabayashi, H. An outbreak of gliding bacterial disease in hatchery-born red seabream (Pegrus major) and gilthead (Acanthopagrus schlegeli) fry in Hiroshima. Fish Pathol. 1977, 12, 171-177. (In Japanese) [CrossRef]

7. Wakabayashi, H.; Hikida, M.; Masumura, K. Flexibacter maritimus sp. nov., a Pathogen of Marine Fishes. Int. J. Syst. Bacteriol. 1986, 36, 396-398. [CrossRef]

8. Handlinger, J.; Soltani, M.; Percival, S. The pathology of Flexibacter maritimus in aquaculture species in Tasmania, Australia. J. Fish Dis. 1997, 20, 159-168. [CrossRef]

9. $\quad$ Frisch, K.; Småge, S.B.; Johansen, R.; Duesund, H.; Brevik, Ø.J.; Nylund, A. Pathology of experimentally induced mouthrot caused by Tenacibaculum maritimum in Atlantic salmon smolts. PLoS ONE 2018, 13, e0206951. [CrossRef]

10. Mabrok, M.; Machado, M.; Serra, C.R.; Afonso, A.; Valente, L.M.P.; Costas, B. Tenacibaculosis induction in the Senegalese sole (Solea senegalensis) and studies of Tenacibaculum maritimum survival against host mucus and plasma. J. Fish Dis. 2016, 39, $1445-1455$. [CrossRef]

11. Bernardet, J.-F.; Kerouault, B.; Michel, C. Comparative Study on Flexibacter maritimus Strains Isolated from Farmed Sea Bass (Dicentrarchus labrax) in France. Fish Pathol. 1994, 29, 105-111. [CrossRef]

12. Nishioka, T.; Watanabe, K.-I.; Sano, M. A Bath Challenge Method with Tenacibaculum maritimum for Japanese Flounder Paralichthys olivaceus. Fish Pathol. 2009, 44, 178-181. [CrossRef]

13. Hasheim, M.H.M.; Haridy, M.H.M. Pathological Findings of Tenacibaculum maritimus Infection in Black Damselfish, Neoglyphieodon melas and Picasso Triggerfish, Rhinecanthus assasi in Red Sea, Egypt. Vet. Sci. Technol. 2014, 6, 6. [CrossRef]

14. Apablaza, P.; Frisch, K.; Brevik, Ø.J.; Småge, S.B.; Vallestad, C.; Duesund, H.; Mendoza, J.; Nylund, A. Primary Isolation and Characterization of Tenacibaculum maritimum from Chilean Atlantic Salmon Mortalities Associated with a Pseudochattonella spp. Algal Bloom. J. Aquat. Anim. Health 2017, 29, 143-149. [CrossRef]

15. Småge, S.B.; Frisch, K.; Brevik, Ø.J.; Watanabe, K.; Nylund, A. First isolation, identification and characterisation of Tenacibaculum maritimum in Norway, isolated from diseased farmed sea lice cleaner fish Cyclopterus lumpus L. Aquaculture 2016, 464, 178-184. [CrossRef]

16. Muniesa, A.; Basurco, B.; Aguilera, C.; Furones, D.; Reverté, C.; Sanjuan-Vilaplana, A.; Jansen, M.D.; Brun, E.; Tavornpanich, S. Mapping the knowledge of the main diseases affecting sea bass and sea bream in Mediterranean. Transbound. Emerg. Dis. 2020, 67, 1089-1100. [CrossRef]

17. ICES; Santos, I.; Pazos, F.; Barja, J.L. Tenacibaculum maritimum, Causal Agent of Tenacibaculosis in Marine Fish. Available online: www.vliz.be/imisdocs/publications/326136.pdf (accessed on 10 December 2021).

18. Bridel, S.; Bourgeon, F.; Marie, A.; Saulnier, D.; Pasek, S.; Nicolas, P.; Bernardet, J.-F.; Duchaud, E. Genetic diversity and population structure of Tenacibaculum maritimum, a serious bacterial pathogen of marine fish: From genome comparisons to high throughput MALDI-TOF typing. Vet. Res. 2020, 51, 1-17. [CrossRef]

19. Avendaño-Herrera, R.; Toranzo, A.E.; Magariños, B. A challenge model for Tenacibaculum maritimum infection in turbot, Scophthalmus maximus (L.). J. Fish Dis. 2006, 29, 371-374. [CrossRef] [PubMed] 
20. Rahman, T.; Suga, K.; Kanai, K.; Sugihara, Y. Biological and Serological Characterization of a Non-gliding Strain of Tenacibaculum maritimum Isolated from a Diseased Puffer Fish Takifugu rubripes. Fish Pathol. 2014, 49, 121-129. [CrossRef]

21. Yamamoto, T.; Kawai, K.; Oshima, S. Evaluation of an Experimental Immersion Infection Method with Tenacibaculum maritimum in Japanese Flounder Paralichthys olivaceus. Aquac. Sci. 2010, 58, 481-489.

22. Baxa, D.V.; Kawai, K.; Kusuda, R. Experimental infection of Flexibacter maritimus in black sea bream (Acanthopagrus schlegeli) fry. Fish Pathol. 1987, 22, 105-109. [CrossRef]

23. Frisch, K.; Småge, S.B.; Vallestad, C.; Duesund, H.; Brevik, Ø.J.; Klevan, A.; Olsen, R.H.; Sjaatil, S.T.; Gauthier, D.; Brudeseth, B.; et al. Experimental induction of mouthrot in Atlantic salmon smolts using Tenacibaculum maritimum from Western Canada. J. Fish Dis. 2018, 41, 1247-1258. [CrossRef]

24. Subramanian, S.; MacKinnon, S.L.; Ross, N.W. A comparative study on innate immune parameters in the epidermal mucus of various fish species. Comp. Biochem. Physiol. Part B Biochem. Mol. Biol. 2007, 148, 256-263. [CrossRef]

25. Qu, W.; Hong, G.; Zhao, J. Degradation of malachite green dye by Tenacibaculum sp. HMG1 isolated from Pacific deep-sea sediments. Acta Oceanol. Sin. 2018, 37, 104-111. [CrossRef]

26. Van Gelderen, R.; Carson, J.; Gudkovs, N.; Nowak, B. Physical Characterisation of Tenacibaculum maritimum for Vaccine Development: T. maritimum for Vaccine Development. J. Appl. Microbiol. 2010, 109, 1668-1676. [CrossRef]

27. Avendaño-Herrera, R.; Rodriguez, J.; Magarinos, B.; Romalde, J.; Toranzo, A. Intraspecific diversity of the marine fish pathogen Tenacibaculum maritimum as determined by randomly amplified polymorphic DNA-PCR. J. Appl. Microbiol. 2004, 96, 871-877. [CrossRef] [PubMed]

28. Re, Y.; Timur, G. Antigenic Characterisation of Tenacibaculum maritimum Isolates from Sea Bass (Dicentrarchus labrax, L.) Farmed on the Aegean Sea Coasts of Turkey. J. Aquac. Res. Dev. 2016, 7. [CrossRef]

29. Avendaño-Herrera, R.; Toranzo, A.E.; Romalde, J.L.; Lemos, M.L.; Magariños, B. Iron Uptake Mechanisms in the Fish Pathogen Tenacibaculum maritimum. Appl. Environ. Microbiol. 2005, 71, 6947-6953. [CrossRef]

30. Yoon, S.-H.; Ha, S.-M.; Kwon, S.; Lim, J.; Kim, Y.; Seo, H.; Chun, J. Introducing EzBioCloud: A taxonomically united database of $16 \mathrm{~S}$ rRNA gene sequences and whole-genome assemblies. Int. J. Syst. Evol. Microbiol. 2017, 67, 1613-1617. [CrossRef]

31. Alix, M.; Gasset, E.; Bardon-Albaret, A.; Noel, J.; Pirot, N.; Perez, V.; Coves, D.; Saulnier, D.; Lignot, J.-H.; Cucchi, P.N. Description of the unusual digestive tract of Platax orbicularis and the potential impact of Tenacibaculum maritimum infection. PeerJ 2020, 8, e9966. [CrossRef]

32. Katoh, K.; Rozewicki, J.; Yamada, K.D. MAFFT online service: Multiple sequence alignment, interactive sequence choice and visualization. Brief. Bioinform. 2019, 20, 1160-1166. [CrossRef]

33. Habib, C.; Houel, A.; Lunazzi, A.; Bernardet, J.-F.; Olsen, A.B.; Nilsen, H.; Toranzo, A.E.; Castro, N.; Nicolas, P.; Duchaud, E. Multilocus Sequence Analysis of the Marine Bacterial Genus Tenacibaculum Suggests Parallel Evolution of Fish Pathogenicity and Endemic Colonization of Aquaculture Systems. Appl. Environ. Microbiol. 2014, 80, 5503-5514. [CrossRef]

34. Jolley, K.A.; Maiden, M.C. BIGSdb: Scalable analysis of bacterial genome variation at the population level. BMC Bioinform. 2010, 11, 595. [CrossRef]

35. Letunic, I.; Bork, P. Interactive tree of life (iTOL) v3: An online tool for the display and annotation of phylogenetic and other trees Nucleic Acids Res. 2016, 44, W242-W245. [CrossRef]

36. Avendaño-Herrera, R.; Magariños, B.; López-Romalde, S.; Romalde, J.; Toranzo, A.; Hartl-Meier, C.; Zang, C.; Dittmar, C.; Esper, J.; Göttlein, A.; et al. Phenotypic characterization and description of two major O-serotypes in Tenacibaculum maritimum strains from marine fishes. Dis. Aquat. Org. 2004, 58, 1-8. [CrossRef]

37. Fringuelli, E.; Savage, P.D.; Gordon, A.; Baxter, E.J.; Rodger, H.D.; Graham, D.A. Development of a Quantitative Real-Time PCR for the Detection of Tenacibaculum Maritimum and Its Application to Field Samples: Real-Time PCR for Tenacibaculum Maritimum. J. Fish Dis. 2012, 35, 579-590. [CrossRef]

38. Close, B.; Banister, K.; Baumans, V.; Bernoth, E.-M.; Bromage, N.; Bunyan, J.; Erhardt, W.; Flecknell, P.; Gregory, N.; Hackbarth, H.; et al. Recommendations for euthanasia of experimental animals: Part 2. Lab. Anim. 1997, 31, 1-32. [CrossRef]

39. Kilkenny, C.; Browne, W.J.; Cuthill, I.C.; Emerson, M.; Altman, D.G. Improving Bioscience Research Reporting: The ARRIVE Guidelines for Reporting Animal Research. PLoS Biol. 2010, 8, e1000412. [CrossRef] 